\title{
Relaxin: Antifibrotic Properties and Effects in Models of Disease
}

\author{
Chrishan S. Samuel, PhD
}

\begin{abstract}
Fibrosis (progressive scarring) is a leading cause of organ failure worldwide and causes loss of organ function when normal tissue is replaced with excess connective tissue. Several organs are prone to this process regardless of etiology. The pleiotropic hormone, relaxin, is emerging as a novel antifibrotic therapy. Relaxin has been shown to limit collagen production and reorganization, while stimulating increased collagen degradation. It not only prevents fibrogenesis, but also reduces established scarring. This review summarizes (I) the levels at which relaxin inhibits collagen production and existing collagen overexpression in induced models of fibrosis, and (2) the collagen-related phenotypes of relaxin- and LGR7-deficient mice. Recent studies on relaxin-deficient mice have established relaxin as an important, naturally occurring regulator of collagen turnover and provide new insights into the therapeutic potential of relaxin.
\end{abstract}

Keywords: Collagen, Gene-knockout mice, Fibrosis, Relaxin

$\mathrm{R}$ range of biological actions in several species. ${ }^{1-9}$ Discovered almost 80 years ago, relaxin was found to be primarily produced in the ovary and/or placenta during pregnancy and was initially regarded as a hormone of pregnancy. ${ }^{1}$ Humans and higher primates have three relaxin genes, designated as $H 1, H 2$ and $H 3$ relaxin, ${ }^{10}$ while two relaxin genes, relaxin- 1 and relaxin-3, exist in rodents and are equivalent to $H 2$ and $H 3$ relaxin, respectively. The $\mathrm{H} 2$ relaxin protein (or relaxin-1 in rodents) is the major circulating and stored form of relaxin in each respective species and, therefore, will be the forms of relaxin referred to in this review. The $H 3$ relaxin gene (or relaxin-3 in rodents) is predominantly expressed in the brain where it is thought to act as a neuropeptide. 5,10 The primary relaxin receptor, LGR7, was only recently identified and is a member of the leucine-rich repeat family of G-protein-coupled receptors. ${ }^{11}$ The identification of these relaxin peptides and the LGR7 receptor in several tissues and cells outside the female reproductive tract and the recently documented novel actions of relaxin ${ }^{1-9}$ have now established relaxin as a pleiotropic hormone with significant therapeutic and clinical implications.
One of the most consistent biological effects of relaxin is its ability to stimulate the breakdown of collagen, a major component of all organs within the body. Relaxin not only stimulates collagen remodeling within the birth canal in preparation for parturition, ${ }^{1}$ but acts on cells and tissues to inhibit fibrosis, the process of tissue scarring which is primarily the result of excessive collagen deposition.

Fibrosis is a universal response to chronic injury and inflammation of several organs and manifests itself as excess accumulation of connective tissue resulting in an irreversible loss of tissue function when normal tissue is replaced by scar tissue. ${ }^{12,13}$ Fibrosis exists in numerous forms, including vascular sclerosis, hepatic cirrhosis, pulmonary fibrosis and renal fibrosis. These forms of deep organ fibrosis are particularly serious because the progressive loss of organ function is a leading cause of mortality estimated to account for $45 \%$ of deaths in the United States between 1984 and $1989 . .^{12}$ It is also noteworthy that the underlying pathology of fibrosis remains similar in all cases suggesting that insights into the pathogenesis of scarring in any one of these organs has important implications for our understanding of fibrosis in general.
Reprint Requests: Chrishan S. Samuel, PhD, Howard Florey Institute, University of Melbourne, Parkville, Victoria 30 I0, Australia; Tel: 6I3-8344-5653; Fax: 6I3-9348-I707; E-mail: c.samuel@hfi.unimelb.edu.au
Received: February 28, 2005

Revised: May 16, 2005

Accepted: July 7, 2005

Grant Support: Grants from the National Health and Medical Research Council of Australia, the Australian Research Council, and BAS Medical Inc. (San Mateo, California). 


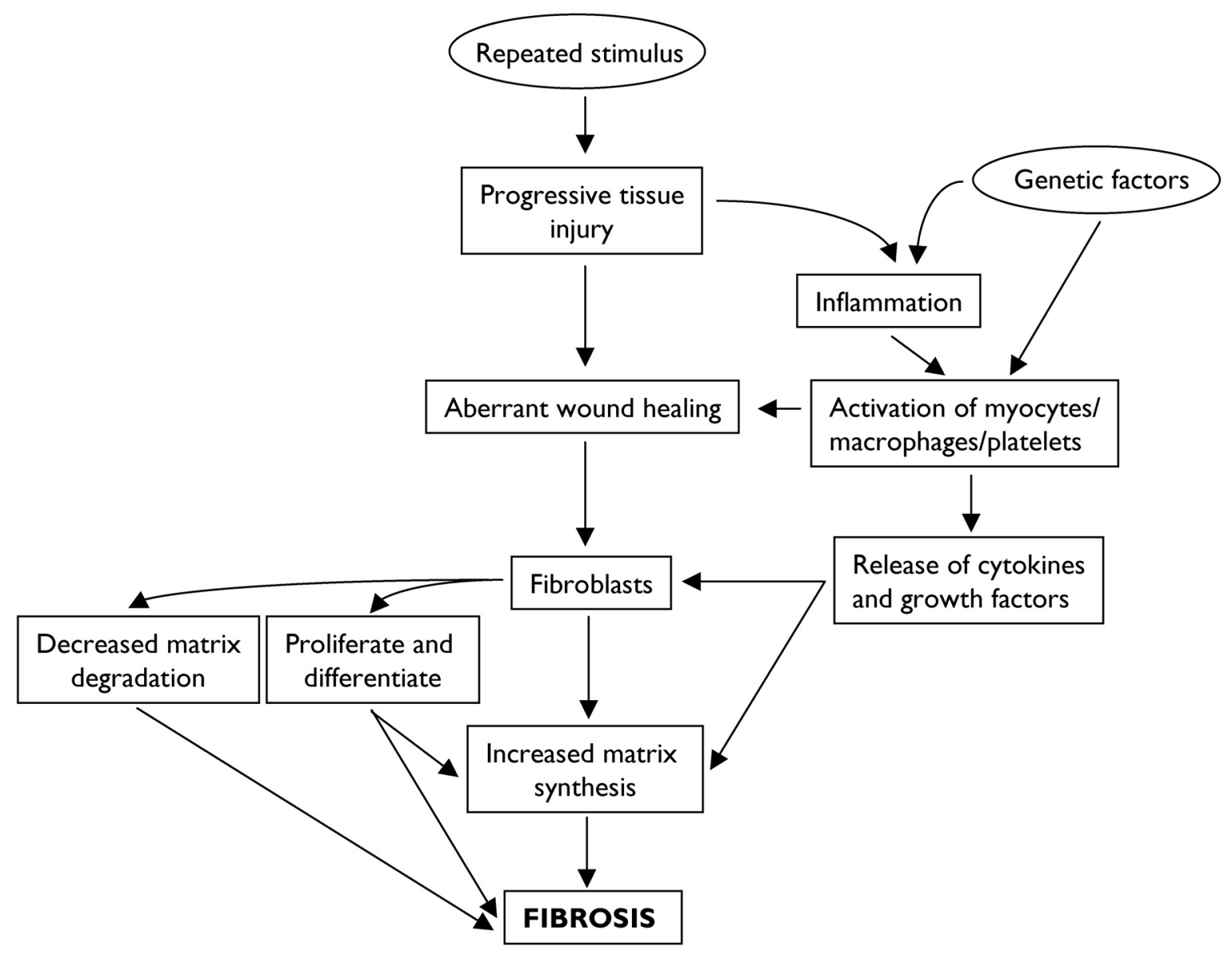

Figure 1. Generalized sequence of events leading from tissue injury to fibrosis. ${ }^{72-74}$

Fibrogenesis is driven by the recruitment of myofibroblasts to the site of injury. Fibroblastic cells are characterized by their expression of the protein, smooth muscle actin (SMA). Stimulated by a variety of cytokines, fibroblasts proliferate, differentiate and synthesize matrix ${ }^{14}$ with the balance between matrix synthesis and remodeling determining the extent of scarring (figure 1). The major profibrotic factors include transforming growth factor- $\beta 1$ (TGF- $\beta 1$ ), 13,15 angiotensin II (AngII) ${ }^{13,16}$ and their downstream mediators including connective tissue growth factor (CTGF), ${ }^{17,18}$ platelet derived growth factor (PDGF) ${ }^{13,19}$ and endothelin-1 (ET-1). ${ }^{13,20}$ Furthermore, an imbalance between collagen degrading enzymes, the matrix metalloproteinases (MMPs) and their inhibitors, the tissue inhibitors of metalloproteinases (TIMPs), can also lead to excessive collagen deposition and result in organ fibrosis. ${ }^{21}$ The irregular deposition of matrix material leads to the disruption of normal tissue architecture and eventually to organ dysfunction.

Since the $1950 \mathrm{~s}$, it has been hypothesized that relaxin could affect the degradation of extracellular matrix molecules leading to connective tissue remodeling in a number of reproductive and non-reproductive tissues. This notion was clinically tested in the 1950s and in the late 1990s in studies on systemic sclerosis (scleroderma), ${ }^{22,23}$ a complex disorder of connective tissue which is characterized clinically by thickening and fibrosis of the skin in addition to interstitial fibrosis of several internal organs, such as the heart, lung, liver and kidneys. ${ }^{23}$ Although relaxin was found to be safe and well tolerated in these clinical trials, it failed to meet the primary efficacy endpoints, highlighting the fact that further work was required to determine the potency and mechanism of action of relaxin as an antifibrotic agent.

\section{The Effects of Relaxin Administration to Models of Induced Fibrotic Disease}

In recent times, a highly purified recombinant form of $\mathrm{H} 2$ relaxin has been produced and tested in a number of in vitro and in vivo systems to evaluate both its ability to modify connective tissue and its potential antifibrotic properties. Several studies have demonstrated that relaxin is able to act at multiple levels to inhibit fibrogenesis and collagen overexpression associated with fibrosis. It is important to note that while several actions of relaxin are consistently identified in multiple organs, some of its actions are tissue specific or vary between organs suggesting that relaxin inhibits fibrosis through common and specific mechanisms, depending on the organ to which it is applied. 


\section{Relaxin inhibits fibroblast function}

Relaxin's ability to inhibit fibroblast proliferation was demonstrated in the late 1980s, when it was shown to prevent the normal course of cell division and inhibit the proliferative response during the inductive phase of differentiation of the 3T3-L1 fibroblast cell line without affecting fibroblast differentiation directly. ${ }^{24}$ More recently, relaxin was shown to directly inhibit fibroblast differentiation into myofibroblast expression by inhibiting alpha-smooth muscle actin ( $\alpha$-SMA) expression in a dose-dependent manner when applied to rat cortical fibroblasts. ${ }^{25}$ While relaxin alone did not appear to directly inhibit renal fibroblast proliferation, it was able to abrogate the TGF- $\beta$-induced reduction in fibroblast number. ${ }^{25}$ In separate studies, relaxin inhibited $\alpha$-SMA expression when applied to rat hepatic stellate cells ${ }^{26}$ and inhibited fibroblast proliferation and differentiation when applied to rat cardiac fibroblasts. These findings are consistent with relaxin's ability to inhibit collagen synthesis and deposition. ${ }^{27}$

Relaxin inhibits collagen synthesis/secretion and deposition Inhibition of collagen synthesis/secretion and accumulation by relaxin has been well documented in several in vitro and in vivo studies. In vitro, relaxin decreases matrix accumulation by inhibiting collagen secretion and/or deposition in a dose-dependent manner (0.1-100 ng/ml) when applied to human dermal fibroblasts ${ }^{28}$ and fibroblasts from scleroderma patients, ${ }^{29}$ human lung fibroblasts, ${ }^{30}$ rat hepatic stellate cells, ${ }^{31}$ rat cortical fibroblasts, ${ }^{25}$ and rat atrial and ventricular fibroblasts. ${ }^{27}$ Relaxin decreased newly formed collagen secretion, even in the presence of collagen overexpression induced by profibrotic factors (TGF- $\beta 1$, interleukin-1 $\beta$ or AngII). This effect was seen in several fibroblast cultures, including rat cardiac fibroblasts (figure 2A). Furthermore, relaxin markedly inhibited collagen deposition into the cell layer of these cultures after pre-stimulation of cells with these same pro-fibrotic factors (figure 2B). In all these in vitro studies, relaxin did not demonstrate any effects on basal collagen expression highlighting the specificity of relaxin's antifibrotic actions to affected (scarred) tissues and not to normal tissue collagen and architecture.

The ability of $\mathrm{H} 2$ relaxin to inhibit collagen deposition and accumulation has also been demonstrated in a number of pre-clinical in vivo experiments involving models of induced fibrosis. Relaxin significantly reduced collagen accumulation over a 2-week period in two rodent models of dermal fibrosis induced by (1) fibrotic infiltration of polyvinyl alcohol sponge implants in rats and (2) capsule formation around implanted osmotic pumps in mice. ${ }^{32}$ In both models, relaxin inhibited collagen deposition by $25 \%-29 \%$ and altered the array of densely packed collagen fibers to those that were less abundant and randomly orientated. $\mathrm{H} 2$ relaxin has also been successfully used to rapidly inhibit collagen overexpression and alveolar thickening in a murine model of bleomycin-induced pulmonary fibrosis. ${ }^{30}$ In separate studies, H2 relaxin inhibited renal interstitial fibrosis and improved glomerular filtration rate in an experimental bromoethylamine rat model $^{33}$ and two rat models of renal mass reduction caused by infarction or surgical excision of both poles. ${ }^{34}$ Consistent with these findings, $\mathrm{H} 2$ relaxin was demonstrated to inhibit collagen content and staining in a carbon tetrachloride-induced rat model of hepatic fibrosis 31 and markedly decreased, by $40 \%-90 \%$, left ventricular collagen concentration in three rodent models of established cardiac fibrosis caused by relaxin-deficiency, ${ }^{22}$ transgenic overexpression of $\beta 2$-adrenoreceptors ${ }^{22}$ or hypertension. ${ }^{35}$ In all of these models, increased collagen deposition had to be induced by surgical, chemical or genetically modified means to be effectively treated by relaxin. However, the underlying trend in these studies was that relaxin could prevent excessive collagen deposition in diseased states characterized by fibrosis. Furthermore, in all of these in vivo models, the effects of relaxin were demonstrated to be rapid and effective when administration resulted in circulating levels of $30 \mathrm{ng} / \mathrm{ml}$ to $50 \mathrm{ng} / \mathrm{ml} \mathrm{-} \mathrm{the} \mathrm{physiological} \mathrm{range} \mathrm{of} \mathrm{serum} \mathrm{relaxin}$ observed in pregnant rodents. 1,36

Relaxin influences the expression and integrity of other matrix components involved in the progression of fibrosis In addition to its ability to inhibit collagen secretion and deposition, relaxin has also been shown to inhibit other matrix components that are up-regulated during fibrogenesis. In vitro, relaxin down-regulates fibronectin (a fibrous linking protein that promotes cellular adhesion and migration) secretion by human dermal ${ }^{23}$ and pulmonary ${ }^{25}$ fibroblasts, while $\mathrm{H} 2$ relaxin inhibited fibronectin expression in an antiglomerular basement membrane rat model of renal fibrosis in vivo. ${ }^{37}$ In separate studies, neutralization of endogenous relaxin in rats caused an increase in elastin fiber length, density and interdigitation in the late pregnant mammary gland, ${ }^{38}$ nipples, ${ }^{39}$ cervix $^{40}$ and vagina. ${ }^{41}$ The ability of relaxin to inhibit elastin expression and integrity in these organs is most likely required for the remodeling that these tissues undergo for successful parturition and lactation, while the significance of this finding in relation to fibrosis is yet to be fully understood. Consistent with these studies, relaxin was shown to inhibit fibrillin-2 (which is thought to play a role in elastogenesis) mRNA and protein expression when applied to human dermal fibroblasts in vitro and the skin of embryonic mice in vivo. ${ }^{42}$ In limited studies, relaxin has also been shown to inhibit glycosaminoglycan content (which is known to play a role in tissue hydration) in fibrocartilaginous joints. 43

Relaxin stimulates MMP expression while inhibiting the expression and activation of TIMPs

Collagen degradation is particularly influenced by the balance of four classes of proteinases, which include aspartic, cysteine, metallo and serine active sites. Relaxin has been shown to act through all four classes of enzymes, ${ }^{44-46}$ although its effects on MMPs and their inhibitors are more prominently documented. Several studies have now 
A
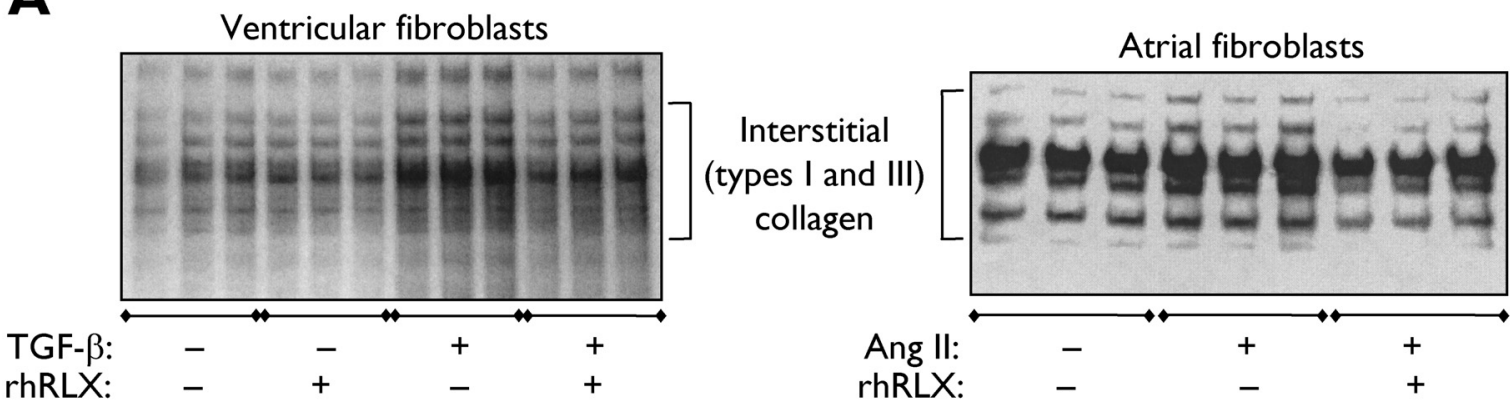

B
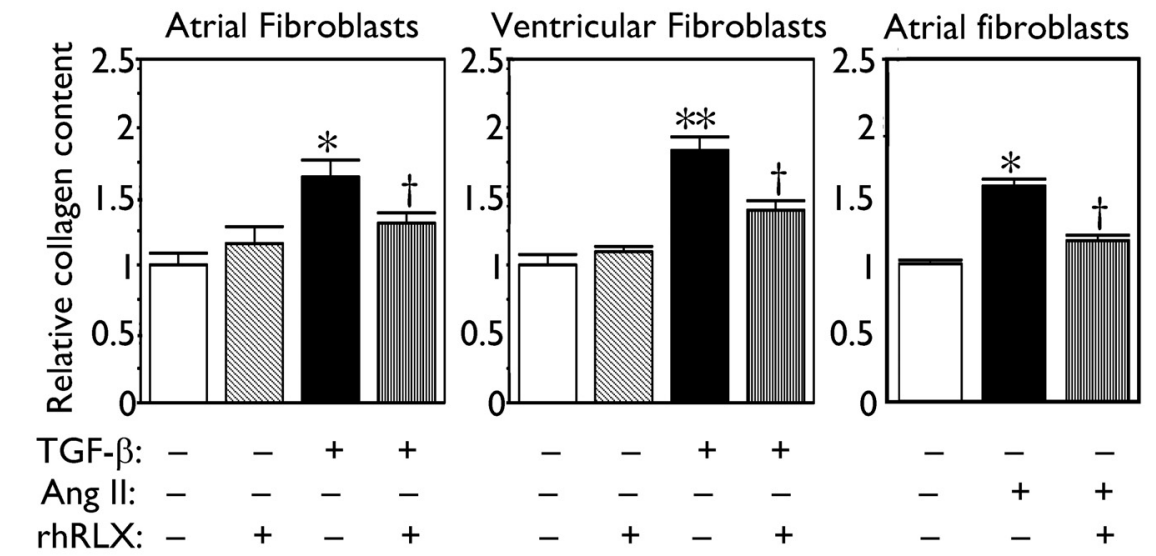

Low-density ventricular

C
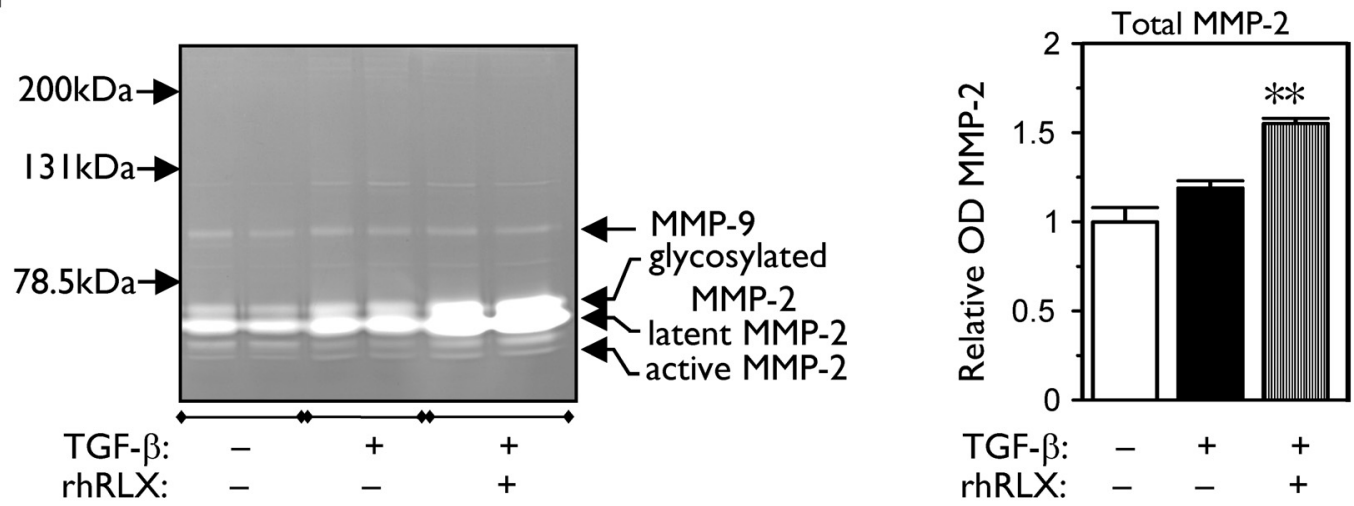

Figure 2. Modulation of collagen synthesis, degradation and deposition by $\mathrm{H} 2$ relaxin when applied to neonatal rat cardiac fibroblasts. ${ }^{27}$ (A) Biosynthetically labeled interstitial collagen from untreated cardiac fibroblasts $\left(2 \times 10^{5} / \mathrm{cm}^{2}\right)$ and cells treated with either $\mathrm{H} 2$ relaxin $(100 \mathrm{ng} / \mathrm{ml})$ alone, TGF- $\beta(1 \mathrm{ng} / \mathrm{ml})$ alone or TGF- $\beta$ and $\mathrm{H} 2$ relaxin, or with Angll $\left(5 \times 10^{-7} \mathrm{M}\right)$ alone or Angll and $\mathrm{H} 2 \mathrm{relaxin}(100 \mathrm{ng} / \mathrm{ml})$ after 72 hours of culture. Shown are representative figures of triplicate samples from three separate experiments. (B) Collagen content of cell layers from untreated fibroblasts and cells treated with $\mathrm{H} 2$ relaxin (100 ng/ml) alone, TGF- $\beta$ ( 2 ng/ml) alone or TGF- $\beta$ and H2 relaxin $(100 \mathrm{ng} / \mathrm{ml})$ after 72 hours of culture. Also shown is the collagen content of cell layers from untreated atrial fibroblasts and cells treated with Angll $\left(10^{-7} \mathrm{M}\right)$ alone or Angll and $\mathrm{H} 2$ relaxin $(100 \mathrm{ng} / \mathrm{ml})$ after 72 hours of culture. Results are presented as the mean + SE 'relative collagen content' from 3-4 separate experiments. ${ }^{*} p<0.05$ and ${ }^{* *} p<0.01$ compared with values from untreated cells. $\dagger, \mathrm{p}<0.05$ compared with values from TGF- $\beta$ or Angll treated cells. Additionally, $\mathrm{H} 2$ relaxin (100 $\mathrm{ng} / \mathrm{ml})$ treatment of low-density cells $\left(5 / \mathrm{mm}^{2}\right)$ over 7 days caused an inhibition of collagen deposition. Results are presented as the mean + SE 'relative collagen content' from 3 separate experiments ( 6 assays per group from each experiment). $\dagger, p<0.05$ compared with values from untreated cells. (C) MMP-2 and -9 expression and activity were determined by gelatin zymography of media from untreated cultures and cells treated with either TGF- $\beta$ ( $2 \mathrm{ng} / \mathrm{ml})$ or TGF- $\beta$ and $\mathrm{H} 2$ relaxin $(100 \mathrm{ng} / \mathrm{ml})$ over 72 hours. Shown is a representative zymograph of duplicate samples from each group from four sets of samples/group. Also shown are the mean + SE 'relative OD MMP-2' of the total MMP-2 (derived from the latent and active forms of MMP-2) as determined by densitometry scanning. (Adapted and reproduced with permission from Samuel CS, et al. Relaxin modulates cardiac fibroblast proliferation, differentiation, and collagen production and reverses cardiac fibrosis in vivo. Endocrinology 2004;145:4125-4133. ${ }^{27}$ Copyright 2004 The Endocrine Society. All rights reserved.) 
demonstrated a relaxin-induced increase in collagen, fibronectin and elastin degradation via its ability to stimulate MMP (-1 [collagenase-1], -2 [gelatinase-A], -3 [stromelysin-1], -9 [gelatinase-B], -12 [elastase] and -13 [collagenase-3]) expression and/or activation when applied to fibroblast cultures from various organs ${ }^{25-28,30,31,47,48}$ and animal models of disease. ${ }^{33,35}$ In some studies, relaxin was able to stimulate MMP (MMP-2/gelatinase-A) expression and activation when administered to rat cardiac fibroblasts 27 in the presence of profibrogenic stimuli, such as TGF- $\beta 1$ (figure 2C) or AngII. Relaxin also inhibited the expression and/or activation of the TIMPs in some of these models ${ }^{28,31}$ as a means of down-regulating extracellular matrix synthesis and deposition. These combined findings demonstrate that relaxin's ability to regulate collagen turnover is achieved in part via its ability to stimulate MMP expression while inhibiting TIMP expression in several species and organs or cells derived from these organs. However, it should be noted that the type of MMP/TIMP affected by relaxin is dependent upon the species and particular organ studied. MMP-1 is the major collagenase affected by relaxin in humans, ${ }^{28,30,48}$ while relaxin-induced changes in MMP-13 (collagenase-3) are primarily observed in rodents. ${ }^{25,26}$ The gelatinases (MMP-2 and MMP-9) and TIMPs are also differentially regulated depending on the species, tissue or origin of cells where relaxin is applied.

\section{Relaxin inhibits the influence of several profibrotic factors} Several cytokines and growth factors play a key role in fibrogenesis by stimulating extracellular matrix production and collagen synthesis and deposition, the most potent being TGF- $\beta 1$, AngII and their down-stream mediators (CTGF, PDGF and ET-1). Relaxin has been well documented to inhibit TGF- $\beta$-induced collagen and/or fibronectin secretion from human dermal ${ }^{28}$ and pulmonary ${ }^{30}$ fibroblasts and when it has been applied to fibroblasts derived from the rat kidney ${ }^{25}$ and heart. ${ }^{27}$ Furthermore, relaxin administration to a rat model of chronic renal disease ${ }^{33}$ resulted in decreased TGF- $\beta$ expression in vivo. In separate experiments, relaxin has also been shown to inhibit the fibrogenic effects of interleukin-1 $\beta, 28$ AngII 27,49 and certain isoforms of insulin-like growth factor $\mathrm{I}^{27}$ while serving as a functional ET-1 antagonist via activation of the mitogen-activated protein kinase (MAPK) pathway. 50 By antagonizing the effects of these profibrotic factors, relaxin decreased collagen secretion in the presence of collagen overexpression (figure $2 \mathrm{~A}$ ) in addition to collagen deposition and accumulation (overexpression) itself (figure 2B).

\section{Collagen-Related Phenotypes in Relaxin and LGR7 Gene-Knockout Mice}

The development of the relaxin gene-knockout (RLX-/-) mouse, ${ }^{51}$ which lacks the major stored and circulating form of mouse relaxin, provided the first evidence that relaxin is an essential endogenous mediator of collagen turnover and protects several organs against fibrosis. In non-reproductive organs, RLX-/- mice demonstrated an age-related progression of interstitial fibrosis in the lung, ${ }^{52}$ heart, ${ }^{53}$ kidneys ${ }^{54}$ and skin, ${ }^{55}$ leading to organ damage and dysfunction. The lungs of RLX-/- mice were associated with marked increases in tissue weight, collagen content and concentration, resulting in the distortion of alveolar structure, lung function and increased bronchiole epithelium thickening. ${ }^{52}$ More recent studies in ageing LGR7 knockout (LGR7-/-) mice have also demonstrated a similar increase in interstitial collagen within the lung, ${ }^{56}$ suggesting that relaxin's actions on collagen turnover in vivo are mediated through LGR7. The heart of RLX-/- mice underwent an increase in atrial hypertrophy and impeded left ventricular (LV) diastolic filling and venous return, which was attributed to progressive increases in LV collagen content and ventricular chamber stiffness. ${ }^{53}$ The kidneys of ageing RLX-/mice were also associated with focal increases in interstitial fibrosis and a more general diffuse increase in glomerulosclerosis, resulting in increased cortical thickening and reduced renal function. 54 Furthermore, RLX-/developed an age-related progression of dermal fibrosis and thickening, which was attributed to marked increases in types I and III collagen. ${ }^{55}$ These combined findings demonstrated that RLX-/- mice undergo an age-related progression of fibrosis in several major organs leading to altered tissue structure and function.

Additionally, several reproductive organs of RLX-/- mice also developed an age- or pregnancy-related progression of fibrosis leading to impaired organ function. Female RLX-/mice in late stages of pregnancy showed inadequate development of the pubic symphysis, nipples, mammary glands and female reproductive organs ${ }^{51}$ resulting in some level of impaired delivery and fetal survival and the inability of RLX-/- mothers to suckle their young. These findings were later correlated to increased interstitial collagen in these organs, particularly in the vagina and nipple. ${ }^{57}$ LGR7-/- mice also demonstrated impaired nipple development during late pregnancy and were unable to feed their young. ${ }^{56,58}$ In separate studies, analysis of male RLX-/- mice demonstrated inadequate reproductive tract development and growth of the prostate, testis and epididymis leading to impaired fertility. ${ }^{59}$ Again, these findings were associated with increased collagen in all these organs and also correlated with decreased sperm maturation (testis) and increased apoptosis (prostate, testis and epididymis) in ageing male mice. In some male LGR7-/- mice, spermatogenesis was also impaired leading to azoospermia and a reduction in fertility, ${ }^{58}$ suggesting a role for LGR7 in the process of male reproductive tract development and function. However, this phenotype was absent in LGR7-/- mice at older ages or in later generations ${ }^{58}$ and from a different genetic background. ${ }^{56}$ Furthermore, LGR7 and LGR8 (the receptor for insulin-3) double mutant males had normal sized prostates and testes, as compared to wild-type control animals, ${ }^{56}$ indicating that the actions of relaxin through LGR8 did not account for the male reproductive phenotypes observed in RLX-/- mice. 
A

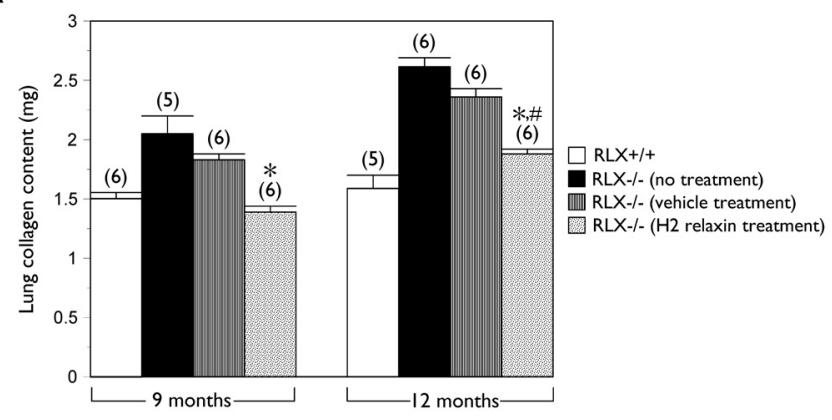

B

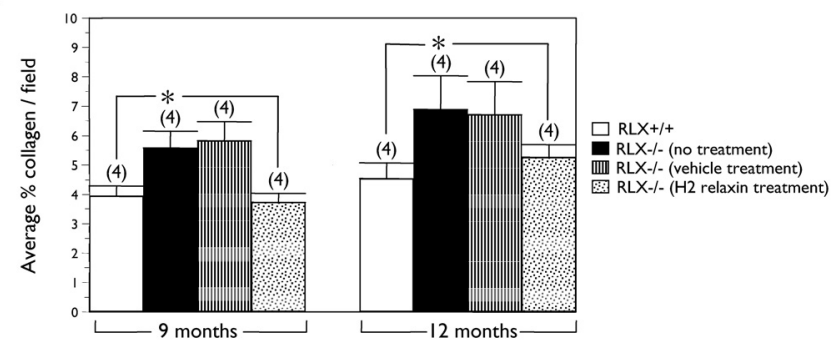

Figure 3. Relaxin-induced reversal of fibrosis. ${ }^{52}$ (A) Total collagen content from the lungs of $R L X+/+$ mice, $R L X-/-$ mice, $\mathrm{RLX}-/$ - mice treated with vehicle (10 $\mathrm{mM}$ sodium acetate buffer) alone and RLX -/- mice treated with $0.5 \mathrm{mg} / \mathrm{kg} /$ day H2 relaxin for 14 days. ${ }^{*}, p<0.05$ when compared with aged-matched untreated- and vehicle-treated RLX -/- mouse lung collagen levels. \#, $p<0.05$ when compared with age-matched $R L X+/+$ mouse lung collagen levels. (B) Quantitative histological analysis of collagen staining was also performed on lung tissues from RLX +/+ and RLX -/- mice before and after $\mathrm{H} 2$ relaxin treatment. The collagen stained area was calculated as a percentage of the total area within random fields from each tissue section analyzed and expressed as the average percentage collagen per field. *, $p<0.05$ when compared with age-matched RLX +/+ and $\mathrm{rH} 2$-treated RLX -/- mouse lung collagen stained levels. (Reproduced with permission Samuel CS, et al. Relaxin deficiency in mice is associated with an age-related progression of pulmonary fibrosis. FASEB $J$ 2003;17:121-123. ${ }^{52}$ Copyright 2003 Federation of American Societies for Experimental Biology. All rights reserved.)

Male RLX-/- mice demonstrated a more rapid and severe progression of cardiac, ${ }^{53}$ pulmonary, ${ }^{52}$ renal $^{54}$ and dermal ${ }^{55}$ fibrosis, similar to what is seen with some forms of human disease. ${ }^{60}$ Whereas female RLX-/- mice developed fibrosis in some organs (skin, lung), the severity of disease was less pronounced and the onset of disease was delayed. Furthermore, in other organs (heart, kidney) they did not demonstrate any changes in collagen accumulation, as compared to that measured in wild-type animals. Thus, the phenotype differences observed between male and female RLX-/- mice may have been the result of using a genetically modified model, which has been reported to cause some organs to display male gender-restricted or gender-biased phenotypes. ${ }^{61}$ Alternatively, these differences may suggest that the presence of androgens in males may have detrimental consequences on the progression of fibrosis, ${ }^{62,63}$ or that other female specific hormones or sex steroids may be compensating for the absence of relaxin in ageing female knockout mice.

\section{The Effects of Relaxin Administration to RLX-/- Mice}

The administration of recombinant $\mathrm{H} 2$ relaxin to RLX-/- mice with an early onset of organ fibrosis resulted in the significant reduction and normalization of collagen concentration to levels measured in respective organs (lung and skin) from age-matched wild-type control $(\mathrm{RLX}+/+)$ mice (figure 3$)^{52}$ over a 2-week treatment period. The rapid ability of relaxin to decrease organ fibrosis at this time point resulted in the restoration of the structural integrity of these tissues to that observed in normal mice. Furthermore, recombinant $\mathrm{H} 2$ relaxin treatment of older RLX-/- mice resulted in significant reversal of established pulmonary (figure 3), ${ }^{52}$ renal $^{54}$ and cardiac $^{27}$ fibrosis by $40 \%-70 \%$ of that measured in untreated RLX-/- mice. In contrast, recombinant $\mathrm{H} 2$ relaxin had no significant effects on established dermal fibrosis when administered to older RLX-/- mice due, most likely, to the increased viscosity of the dermis compared to the other organs and/or to permanent damage to the internal structure of the skin at this time point. These combined studies demonstrate that there is a narrow window within which relaxin alone can successfully be used as a modulator of collagen expression and as an antifibrotic therapy for dermal scarring. These findings are of particular importance given that clinical trials on recombinant $\mathrm{H} 2$ relaxin's effects on systemic sclerosis recently demonstrated that relaxin was biologically active and well tolerated in humans. ${ }^{23}$ While $\mathrm{H} 2$ relaxin treatment benefited only some individuals, the primary efficacy of relaxin as an antifibrotic agent was not met in phase II/III of these trials due to the addition of several patients with end-stage scleroderma that appeared to be untreatable. These clinical findings are consistent with our studies on knockout mice ${ }^{52-55}$ demonstrating that the potency and efficacy of relaxin as an antifibrotic agent is lost when applied to more severe stages of organ fibrosis. Before relaxin can successfully be developed for clinical use, further work is required to determine (1) the optimal dosage, timing and route of relaxin administration to organs undergoing different stages (acute, established or chronic) of fibrosis, (2) the regulation and activation of LGR7 upon ligand binding in diseased states, and (3) the signaling mechanisms by which relaxin down-regulates matrix proteins that are increased during organ scarring. However, on the basis of the studies published to date, relaxin has emerged as a potential antifibrotic agent that appears to play important roles in the regulation of vasodilation, wound healing, airway remodeling and organ protection. ${ }^{1-9}$

\section{Relaxin Signaling}

While it is clear that relaxin has important antifibrotic effects in many tissues, the mechanisms involved are less well understood. The signaling pathways utilized by LGR7 include activation of the stimulatory G-protein $\left(\mathrm{G}_{\mathrm{s}}\right)$ which in turn activates adenylyl cyclase to increase intracellular cyclic AMP levels (figure 4). ${ }^{11,64,65}$ However, there are a number of anomalies that call into question the adenylate cyclase 


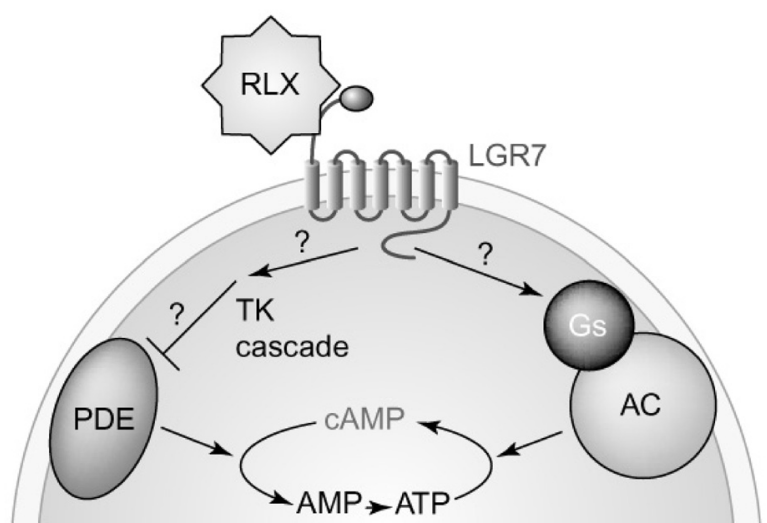

Figure 4. Model of possible signal transduction mechanisms generating cAMP in relaxin-stimulated cells. Conventionally, the relaxin receptor, LGR7, would be expected to stimulate adenylcyclase $(A C)$ via a $G_{s}$-protein intermediate. However, considerable pharmacological evidence supports an alternative pathway involving a tyrosine kinase (TK) cascade (probably employing a mitogen-activated protein kinase) to inhibit a specific phosphodiesterase (PDE), thereby causing an effective upregulation of cAMP. (Reproduced with permission from Ivell R, Einspanier A. Relaxin peptides are new global players. Trends Endocrinol Metab 2002;13:343348. ${ }^{65}$ Copyright 2002 Elsevier. All rights reserved.)

pathway as the sole signal transduction mechanism utilized by relaxin. In human lower uterine segment fibroblasts, relaxin-induced tyrosine phosphorylation is not accompanied by an increase in cAMP. ${ }^{66}$ In human endometrial stromal cells ${ }^{65}$ and the monocytic cell line, THP-1, ${ }^{67}$ relaxin stimulated cAMP accumulation is inhibited by tyrosine kinase inhibitors. Even in tissues where a cAMP response to relaxin is detectable, it is extremely weak when compared with $\beta_{2}$-adrenoceptor stimulation, 68 which is known to signal through $\mathrm{G}_{\mathrm{s}}$ or forskolin that directly stimulates adenylate cyclase. A further complication is the observation that the changes in cAMP tend to follow rather than precede the response and often require the presence of a phosphodiesterase inhibitor to be observed (figure 4). ${ }^{65,69} \mathrm{In}$ human endometrial cells, relaxin increases cAMP but also strongly activates p42/44 MAPK and extracellular signal-regulated kinase. ${ }^{70}$ Similar MAPK activation and antagonism of ET-1 by relaxin are observed in human umbilical vein endothelial cells and HeLa cells. ${ }^{50}$ Relaxin also activates the PI-3-kinase signaling pathway 68,71 and potentially mediates its inhibitory effects on TGF- $\beta$ in various organs and cells $25,27,28,30,33$ via these MAPK/PI-3 kinase pathways or through Smad signaling. Thus, it is clear that relaxin, like many other ligands for G-protein-coupled receptors, is capable of activating multiple signal transduction pathways.

\section{Conclusions}

Relaxin is emerging as an important, naturally occurring inhibitor of collagen turnover in several organs within the body, and also appears to play a protective role in these tissues during normal development and growth in several mammalian species. Additionally, exogenous relaxin is well documented as being a potent and specific antifibrotic agent of affected (diseased) tissues but does not appear to influence the extracellular matrix under normal (basal) conditions. Elucidating the mechanisms by which relaxin induces its effects on collagen and the extracellular matrix will be essential in determining its most effective use as an antifibrotic therapy.

\section{Acknowledgments}

The author would like to thank Professor Geoffrey Tregear and Dr. Ross Bathgate for helpful suggestions regarding this review article.

\section{References}

1. Sherwood OD. Relaxin's physiological roles and other diverse actions. Endocr Rev 2004;25:205-234.

2. Conrad KP, Novak J. Emerging role of relaxin in renal and cardiovascular function. Am J Physiol Regul Integr Comp Physiol 2004;287:R250-R261.

3. McKinley MJ, Cairns MJ, Denton DA, Egan G, Mathai ML, Uschakov A, Wade JD, Weisinger RS, Oldfield BJ. Physiological and pathophysiological influences on thirst. Physiol Behav 2004;81:795-803.

4. Silvertown JD, Summerlee AJ, Klonisch T. Relaxin-like peptides in cancer. Int J Cancer 2003;107:513-519.

5. Bathgate RA, Samuel CS, Burazin TC, Gundlach AL, Tregear GW. Relaxin: new peptides, receptors and novel actions. Trends Endocrinol Metab 2003;14:207-213.

6. Samuel CS, Parry LJ, Summers RJ. Physiological or pathological - a role for relaxin in the cardiovascular system? Curr Opin Pharmacol 2003;3:152-158.

7. Ivell R, Einspanier A. Relaxin peptides are new global players. Trends Endocrinol Metab 2002;13:343-348.

8. Weiss G, Goldsmith LT. Relaxin and the cervix. Front Horm Res 2001;27:105-112.

9. Bani D. Relaxin: a pleiotropic hormone. Gen Pharmacol 1997;28:13-22.

10. Bathgate RA, Samuel CS, Burazin TC, Layfield S, Claasz AA, Reytomas IG, Dawson NF, Zhao C, Bond C, Summers RJ, Parry LJ, Wade JD, Tregear GW. Human relaxin gene 3 (H3) and the equivalent mouse relaxin (M3) gene. Novel members of the relaxin peptide family. J Biol Chem 2002;277:1148-1157.

11. Hsu SY, Nakabayashi K, Nishi S, Kumagai J, Kudo M, Sherwood OD, Hsueh AJ. Activation of orphan receptors by the hormone relaxin. Science 2002;295:671-674.

12. Bitterman PB, Henke CA. Fibroproliferative disorders. Chest 1991;99:81S-84S.

13. Eddy AA. Molecular basis of renal fibrosis. Pediatr Nephrol 2000;15:290-301.

14. Kissin E, Korn JH. Apoptosis and myofibroblasts in the pathogenesis of systemic sclerosis s. Curr Rheumatol Rep 2002;4:129-135.

15. Yu L, Border WA, Huang Y, Noble NA. TGF-beta isoforms in renal fibrogenesis. Kidney Int 2003;64:844-856.

16. Lijnen PJ, Petrov VV, Fagard RH. Induction of cardiac fibrosis by angiotensin II. Methods Find Exp Clin Pharmacol 2000;22:709-723.

17. Zhao Q, Chen N, Wang WM, Lu J, Dai BB. Effect of transforming growth factor-beta on activity of connective tissue growth factor gene promoter in mouse NIH/3T3 fibroblasts. Acta Pharmacol Sin 2004;25:485-489.

18. Xie S, Sukkar MB, Issa R, Oltmanns U, Nicholson AG, Chung KF. Regulation of TGF-beta 1-induced connective tissue growth factor expression in airway smooth muscle cells. Am J Physiol Lung Cell Mol Physiol 2005;288:L68-L76. 
19. Dietz R, von Harsdorf R, Gross M, Kramer J, Gulba D, Willenbrock R, Osterziel KJ. Angiotensin II and coronary artery disease, congestive heart failure, and sudden cardiac death. Basic Res Cardiol 1998;93(suppl 2):101-108.

20. Sugo S, Minamino N, Shoji H, Isumi Y, Nakao K, Kangawa K, Matsuo H. Regulation of endothelin-1 production in cultured rat vascular smooth muscle cells. J Cardiovasc Pharmacol 2001;37:25-40.

21. Benjamin IJ. Matrix metalloproteinases: from biology to therapeutic strategies in cardiovascular disease. J Investig Med 2001;49:381-397.

22. Casten GG, Boucek RJ. Use of relaxin in the treatment of scleroderma. J Am Med Assoc 1958;166:319-324.

23. Erikson MS, Unemori EN. Relaxin clinical trial in systemic sclerosis. In: Tregear GW, Ivell R, Bathgate RA, Wade JD, eds. Relaxin 2000: Proceedings of the third international conference on relaxin and related peptides. Amsterdam, The Netherlands: Kluwer Publishers; 2001;373-381.

24. Pawlina W, Larkin LH, Frost SC. Effect of relaxin on differentiation of 3T3-L1 preadipocytes. Endocrinology 1989;125:2049-2055.

25. Masterson R, Hewitson TD, Kelynack K, Martic M, Parry L, Bathgate R, Darby I, Becker G. Relaxin down-regulates renal fibroblast function and promotes matrix remodelling in vitro. Nephrol Dial Transplant 2004; 19:544-552.

26. Bennett RG, Kharbanda KK, Tuma DJ. Inhibition of markers of hepatic stellate cell activation by the hormone relaxin. Biochem Pharmacol 2003;66:867-874.

27. Samuel CS, Unemori EN, Mookerjee I, Bathgate RA, Layfield SL, Mak J, Tregear GW, Du XJ. Relaxin modulates cardiac fibroblast proliferation, differentiation, and collagen production and reverses cardiac fibrosis in vivo. Endocrinology 2004;145:4125-4133.

28. Unemori EN, Amento EP. Relaxin modulates synthesis and secretion of procollagenase and collagen by human dermal fibroblasts. J Biol Chem 1990;265:10681-10685.

29. Unemori EN, Bauer EA, Amento EP. Relaxin alone and in conjunction with interferon-gamma decreases collagen synthesis by cultured human scleroderma fibroblasts. J Invest Dermatol 1992;99:337-342.

30. Unemori EN, Pickford LB, Salles AL, Piercy CE, Grove BH, Erikson ME, Amento EP. Relaxin induces an extracellular matrix-degrading phenotype in human lung fibroblasts in vitro and inhibits lung fibrosis in a murine model in vivo. J Clin Invest 1996;98:2739-2745.

31. Williams EJ, Benyon RC, Trim N, Hadwin R, Grove BH, Arthur MJ, Unemori EN, Iredale JP. Relaxin inhibits effective collagen deposition by cultured hepatic stellate cells and decreases rat liver fibrosis in vivo. Gut 2001;49:577-583.

32. Unemori EN, Beck LS, Lee WP, Xu Y, Siegel M, Keller G, Liggitt HD, Bauer EA, Amento EP. Human relaxin decreases collagen accumulation in vivo in two rodent models of fibrosis. J Invest Dermatol 1993;101:280-285.

33. Garber SL, Mirochnik Y, Brecklin CS, Unemori EN, Singh AK, Slobodskoy L, Grove BH, Arruda JA, Dunea G. Relaxin decreases renal interstitial fibrosis and slows progression of renal disease. Kidney Int 2001;59:876-882.

34. Garber SL, Mirochnik Y, Brecklin C, Slobodskoy L, Arruda JA, Dunea G. Effect of relaxin in two models of renal mass reduction. Am J Nephrol 2003;23:8-12.

35. Lekgabe ED, Kiriazis H, Zhao C, Xu Q, Moore XL, Su Y, Bathgate RA, Du XJ, Samuel CS. Relaxin reverses cardiac and renal fibrosis in spontaneously hypertensive rats. Hypertension 2005;46:412-418.

36. Sherwood OD, Crnekovic VE, Gordon WL, Rutherford JE. Radioimmunoassay of relaxin throughout pregnancy and during parturition in the rat. Endocrinology 1980;107:691-698.
37. McDonald GA, Sarkar P, Rennke H, Unemori E, Kalluri R, Sukhatme VP. Relaxin increases ubiquitin-dependent degradation of fibronectin in vitro and ameliorates renal fibrosis in vivo. Am J Physiol Renal Physiol 2003;285:F59-F67.

38. Hwang JJ, Lee AB, Fields PA, Haab LM, Mojonnier LE, Sherwood OD. Monoclonal antibodies specific for rat relaxin. V. Passive immunization with monoclonal antibodies throughout the second half of pregnancy disrupts development of the mammary apparatus and, hence, lactational performance in rats. Endocrinology 1991;129:3034-3042.

39. Kuenzi MJ, Sherwood OD. Monoclonal antibodies specific for rat relaxin. VII. Passive immunization with monoclonal antibodies throughout the second half of pregnancy prevents development of normal mammary nipple morphology and function in rats. Endocrinology 1992;131:1841-1847.

40. Lee AB, Hwang JJ, Haab LM, Fields PA, Sherwood OD. Monoclonal antibodies specific for rat relaxin. VI. Passive immunization with monoclonal antibodies throughout the second half of pregnancy disrupts histological changes associated with cervical softening at parturition in rats. Endocrinology 1992;130:2386-2391.

41. Zhao S, Sherwood OD. Monoclonal antibodies specific for rat relaxin. X. Endogenous relaxin induces changes in the histological characteristics of the rat vagina during the second half of pregnancy. Endocrinology 1998;139:4726-4734.

42. Samuel CS, Sakai LY, Amento EP. Relaxin regulates fibrillin 2, but not fibrillin 1, mRNA and protein expression by human dermal fibroblasts and murine fetal skin. Arch Biochem Biophys 2003;411:47-55.

43. Naqvi T, Duong TT, Hashem G, Shiga M, Zhang Q, Kapila S. Relaxin's induction of metalloproteinases is associated with the loss of collagen and glycosaminoglycans in synovial joint fibrocartilaginous explants. Arthritis Res Ther 2005;7:R1-R11.

44. McDonald JK, Schwabe C. Relaxin-induced elevations of cathepsin B and dipeptidyl peptidase I in the mouse pubic symphysis, with localization by fluorescence enzyme histochemistry. Ann N Y Acad Sci 1982;380:178-186.

45. Poisner AM, Thrailkill K, Poisner R, Handwerger S. Relaxin stimulates the synthesis and release of prorenin from human decidual cells: evidence for autocrine/paracrine regulation. $\mathrm{J}$ Clin Endocrinol Metab 1990;70:1765-1767.

46. Too CK, Bryant-Greenwood GD, Greenwood FC. Relaxin increases the release of plasminogen activator, collagenase, and proteoglycanase from rat granulosa cells in vitro. Endocrinology 1984;115:1043-1050.

47. Chen B, Wen Y, Yu X, Polan ML. Elastin metabolism in pelvic tissues: is it modulated by reproductive hormones? Am J Obstet Gynecol 2005;192:1605-1613.

48. Palejwala S, Stein DE, Weiss G, Monia BP, Tortoriello D, Goldsmith LT. Relaxin positively regulates matrix metalloproteinase expression in human lower uterine segment fibroblasts using a tyrosine kinase signaling pathway. Endocrinology 2001;142:3405-3413.

49. Dschietzig T, Richter C, Bartsch C, Laule M, Armbruster FP, Baumann G, Stangl K. The pregnancy hormone relaxin is a player in human heart failure. FASEB J 2001;15:2187-2195.

50. Dschietzig T, Bartsch C, Richter C, Laule M, Baumann G, Stangl K. Relaxin, a pregnancy hormone, is a functional endothelin-1 antagonist: attenuation of endothelin-1-mediated vasoconstriction by stimulation of endothelin type-B receptor expression via ERK-1/2 and nuclear factor-kappaB. Circ Res 2003;92:32-40.

51. Zhao L, Roche PJ, Gunnersen JM, Hammond VE, Tregear GW, Wintour EM, Beck F. Mice without a functional relaxin gene are unable to deliver milk to their pups. Endocrinology 1999; 140:445-453. 
52. Samuel CS, Zhao C, Bathgate RA, Bond CP, Burton MD, Parry LJ, Summers RJ, Tang ML, Amento EP, Tregear GW. Relaxin deficiency in mice is associated with an age-related progression of pulmonary fibrosis. FASEB J 2003;17:121-123.

53. Du XJ, Samuel CS, Gao XM, Zhao L, Parry LJ, Tregear GW. Increased myocardial collagen and ventricular diastolic dysfunction in relaxin deficient mice: a gender-specific phenotype. Cardiovasc Res 2003;57:395-404.

54. Samuel CS, Zhao C, Bond CP, Hewitson TD, Amento EP, Summers RJ. Relaxin-1-deficient mice develop an age-related progression of renal fibrosis. Kidney Int 2004;65:2054-2064.

55. Samuel CS, Zhao C, Yang Q, Wang H, Tian H, Tregear GW, Amento EP. The relaxin gene knockout mouse: a model of progressive scleroderma. J Invest Dermatol 2005;125:692-699.

56. Kamat AA, Feng S, Bogatcheva NV, Truong A, Bishop CE, Agoulnik AI. Genetic targeting of relaxin and insulin-like factor 3 receptors in mice. Endocrinology 2004;145:4712-4720.

57. Zhao L, Samuel CS, Tregear GW, Beck F, Wintour EM. Collagen studies in late pregnant relaxin null mice. Biol Reprod 2000;63:697-703.

58. Krajnc-Franken MA, van Disseldorp AJ, Koenders JE, Mosselman S, van Duin M, Gossen JA. Impaired nipple development and parturition in LGR7 knockout mice. Mol Cell Biol 2004;24:687-696.

59. Samuel CS, Tian H, Zhao L, Amento EP. Relaxin is a key mediator of prostate growth and male reproductive tract development. Lab Invest 2003;83:1055-1067.

60. Neugarten J, Acharya A, Silbiger SR. Effect of gender on the progression of nondiabetic renal disease: a meta-analysis. J Am Soc Nephrol 2000;11:319-329.

61. Du XJ. Gender modulates cardiac phenotype development in genetically modified mice. Cardiovasc Res 2004;63:510-519.

62. Muller V, Szabo A, Viklicky O, Gaul I, Portl S, Philipp T, Heemann UW. Sex hormones and gender-related differences: their influence on chronic renal allograft rejection. Kidney Int 1999;55:2011-2020.

63. Gao XM, Agrotis A, Autelitano DJ, Percy E, Woodcock EA, Jennings GL, Dart AM, Du XJ. Sex hormones and cardiomyopathic phenotype induced by cardiac beta 2-adrenergic receptor overexpression. Endocrinology 2003;144:4097-4105.

64. Bartsch O, Bartlick B, Ivell R. Relaxin signalling links tyrosine phosphorylation to phosphodiesterase and adenylyl cyclase activity. Mol Hum Reprod 2001;7:799-809.

65. Ivell R, Einspanier A. Relaxin peptides are new global players. Trends Endocrinol Metab 2002;13:343-348.

66. Palejwala S, Stein D, Wojtczuk A, Weiss G, Goldsmith LT. Demonstration of a relaxin receptor and relaxin-stimulated tyrosine phosphorylation in human lower uterine segment fibroblasts. Endocrinology 1998;139:1208-1212.

67. Parsell DA, Mak JY, Amento EP, Unemori EN. Relaxin binds to and elicits a response from cells of the human monocytic cell line, THP-1. J Biol Chem 1996;271:27936-27941.

68. Nguyen BT, Yang L, Sanborn BM, Dessauer CW. Phosphoinositide 3-kinase activity is required for biphasic stimulation of cyclic adenosine 3',5'-monophosphate by relaxin. Mol Endocrinol 2003;17:1075-1084.

69. Bartsch O, Bartlick B, Ivell R. Phosphodiesterase 4 inhibition synergizes with relaxin signaling to promote decidualization of human endometrial stromal cells. J Clin Endocrinol Metab 2004;89:324-334.

70. Zhang Q, Liu SH, Erikson M, Lewis M, Unemori E. Relaxin activates the MAP kinase pathway in human endometrial stromal cells. J Cell Biochem 2002;85:536-544.

71. Nguyen BT, Dessauer CW. Relaxin stimulates protein kinase C zeta translocation: requirement for cyclic adenosine

3',5'-monophosphate production. Mol Endocrinol 2005;19:1012-1023.
72. Franklin TJ. Therapeutic approaches to organ fibrosis. Int $J$ Biochem Cell Biol 1997;29:79-89.

73. Gross TJ, Hunninghake GW. Idiopathic pulmonary fibrosis. N Engl J Med 2001;345:517-525.

74. Klahr S, Morrissey J. Obstructive nephropathy and renal fibrosis. Am J Physiol Renal Physiol 2002;283:F861-F875.

\section{Author Affiliation}

Chrishan S. Samuel, PhD, Howard Florey Institute of Experimental Physiology \& Medicine and Department of Biochemisty \& Molecular Biology, The University of Melbourne, Victoria 3010, Australia 